\title{
1. Introduction to the Handbook of Entrepreneurship and Marketing
}

\author{
Ian Fillis and Nicholas Telford
}

Both entrepreneurship and marketing have long histories from practice-based perspectives, but they are both relatively 'new' academic disciplines when compared to long-standing domains such as theology (Hagglund 2007), philosophy (Copleston 1946), mathematics (Boyer and Merzbach 2011) and astronomy (Neugebauer 2012). The Classics and art history also have a longer past as academic subjects (Conley 1927), although the Journal of Historical Research in Marketing publishes work on marketing history and the history of marketing thought. Efforts are also being made at tracing the origins of researching entrepreneurship (e.g. Landstrom and Lohrke 2010). This Handbook appraises the contributions which entrepreneurship and marketing have made, and continue to make, in both theoretical and practical terms, drawing on relevant examples where appropriate. The chapter authors reflect on their research findings in a critical sense in order to help us consider the future of entrepreneurship and marketing (Alvesson and Deetz 2000). Their development is set against the backdrop of an evolving business environment, with contemporary market conditions becoming increasingly influenced by chaos, complexity and ambiguity (Fillis and Rentschler 2006). Instead of a planned, linear rational response to these conditions as recommended by decades of prescriptive textbook thinking (Deshpande 1999; Fillis 2007), an alternative entrepreneurial response is now preferred by many organisations as they leverage their creative resources and competencies in the marketplace (Fillis 2002, 2010). This approach is also supported by the growing criticisms of a continued customer-centric focus in marketing which has resulted in a lack of innovation and truly innovative products, services and experiences, as well as the restriction of company growth (Sheth et al. 2000; Eggers et al. 2013; Joshi 2016). Market creation, rather than market following, should be the priority for many proactive companies, given the shift in consumer behaviour to demanding novelty in the marketplace, accompanied by shorter and shorter technology and product life cycles (Fillis 2006; Gaddefors and Anderson 2009; Lehman et al. 2014). The understanding of marketing practice has been deemed reliant on established, formulaic ways of thinking within a functionalist silo, rather than a creative response to market opportunities (Kotler and Levy 1969; Morris et al. 2002). Its research has also been deemed to be distant from actual practice, with a tactical focus and limited consideration of how it connects with other business areas. There is also a growing consensus that marketing (and consumer research) needs to develop a broader cross-functional, cross-disciplinary orientation (e.g. Deshpande 1999; Arnould and Thompson 2005; Goulding 2005; Libai et al. 2010; Colbert and St-James 2014; Hill and Martin 2014). Marketing is an essential contributor to the creation, development and sustainability of new ventures through its associations with idea generation and creativity, but this has not received much research attention to date, apart from the relationship with market orientation (Lam and Harker 2015).

We also set out in this Handbook how the interface between the marketing and entrepreneurship domains is receiving increasing attention from researchers as a fruitful way of 
understanding business growth through opportunity recognition, networking and competency exploitation. New venture creation is one of the main areas of interest from entrepreneurship researchers (Gartner 1985; Bhave 1994; Neck et al. 2004; Miles et al. 2015). Mitchelmore and Rowley (2010) provide detailed insight into the meaning and nature of competencies from an entrepreneurial perspective but which also have resonance for marketing. In either case, having a set of relevant competencies contributes to the securing of superior performance and heightened business success (Boyatzis 1992). Major entrepreneurial marketing management competencies identified by Carson et al. (1995) relate to experience of the industry and the job; knowledge of the product and market; communication skills in directing the organisation; and sound judgement in being able to identify market opportunities and suitable personnel. It is over 20 years since Carson et al. developed their competency spectrum and this still has relevance today. This robustness is also identified by Fillis (2002) in his work on creativity.

There have also been calls for the rethinking of the research methodologies and theory utilised in understanding both marketing and entrepreneurship (e.g. Hunt 1994; Brownlie et al. 1998; Howorth et al. 2005; Schindehutte et al. 2009; Fayolle and Riot 2015). This re-evaluation can be viewed in a critical sense in contributing to understanding contemporary practices and behaviours (Peredo and McLean 2006; Saren et al. 2007; Tadajewski and Brownlie 2008; Blackburn and Kovalainen 2009; Gartner 2010; Tedmanson et al. 2012). Instead of the perpetuation of general principles of marketing and entrepreneurship, we believe that what is required for the future sustainability of the disciplines are more relevant understandings which account for the impact of contextualised rather than uniformly shaped behaviours (Deacon and Harris 2011). This Handbook addresses these issues by informing researchers, students and practitioners of the merits of effective entrepreneurial, marketing and entrepreneurial marketing practices and, where relevant, supporting theory.

Reflecting on the development of the entrepreneurial marketing domain at that time, Carson et al. (1995) evaluated what was happening in terms of owner/manager experience, knowledge, communication strengths and judgement abilities. Day (1997) pictures the interface as involving a particular organisational form, putting entrepreneurship into marketing, putting marketing into entrepreneurship, relevant competencies and similar and dissimilar characteristics and behaviour. This intersection could also be visualised as a continuum. Shaw (1999) views entrepreneurial marketing as a way to describe the innovative or creative use of an organisation's resources while Morris et al. (2002:5) note how entrepreneurial marketing has tended to be mostly associated with small firms which have limited resources, and consequently become reliant on creative, unsophisticated tactics which draw largely on personal networks. It has also been associated with the visionary entrepreneur who develops unplanned, non-linear forms of marketing. Morris et al. (2002:5) define the intersection as:

the proactive identification and exploitation of opportunities for acquiring and retaining profitable customers through innovative approaches to risk management, resource leveraging and value creation.

They see the basic premise as contributing to sustainable competitive advantage through value creating innovation. Bjerke and Hultman (2002) see entrepreneurial marketing as the marketing of small firms growing through entrepreneurship. Importantly, Hills et al. (2008) note how firms exhibiting entrepreneurial tendencies cannot be understood from mainstream marketing perspectives. It can be argued then that entrepreneurial marketing emerged as a creative response to contemporary market conditions, rather than initially through theoretical 
advancement. Given the role and impact of the owner/manager in creating situation-specific entrepreneurial marketing activities, it can also be argued that a general theory of entrepreneurial marketing is difficult to construct. Instead, advice or knowledge emerges regarding potential entrepreneurial marketing strategies and best practice. Morrish (2011) views entrepreneurial marketing as an augmented process with entrepreneur and customer being core actors in co-creating value in the marketing environment. Proactivity, calculated risk taking, passion and creativity have key roles in shaping entrepreneurial marketing orientation (Miles et al. 2015). Although internal business resources may be limited in small firms, expert use is often made of leveraging existing resources while also accessing external resources through networking via personal (informal) and business (formal) contacts (Gilmore et al. 2001). Entrepreneurial marketers are able to make existing resources last longer than their competitors can in finding innovative uses for these resources in order to achieve higher value. Information obtained via networking tends to be free, and often results in improved insight into market information and advice, customers, pricing, communication and saving time and money on costly market research reports. Much academic entrepreneurial marketing research activity concentrates on the pre start-up and start-up stages of the enterprise (Hoy 2008) but it should also concern the ongoing development of the business over time. The practice of entrepreneurial marketing can result in competitive advantage for the organisation and is found in many small and medium-sized enterprises (SMEs) but it can also be located in organisations of all sizes and sectors (Solé 2013). Morrish et al. (2015) see entrepreneurial marketing as being capable of stimulating businesses, organisations and governments to adopt more effective practices beyond conventional entrepreneurial and marketing approaches which have now outlived their usefulness. Whalen et al. (2016:7) view entrepreneurial marketing's role as ultimately being able to contribute value to society:

EM [entrepreneurial marketing] is a combination of innovative, proactive and risk-taking activities that create, communicate and deliver value to and by customers, entrepreneurs, marketers, their partners and society at large.

They note that entrepreneurial marketing is a form of marketing focused on proactive creation and exploitation of markets using innovation and innovative behaviour at any stage of the business, as well as involving a complex utilisation of a variety of marketing techniques. It is creative and involves a high level of effectuation in its implementation (Sarasvathy 2009), shaped by key actors' entrepreneurial orientation. This results in value creation in terms of customer value, innovation and new market opportunities. As part of the process, effectuation logic (Sarasvathy 2001) can be used to explain how and why the entrepreneurial marketer uses the means at his or her disposal to create this value. The perspectives of who they are, who they know and what they know are also leveraged here. This lens is also adopted by Fillis et al. (2016) in their work on the creation of a privately funded art museum and associated product portfolio, which has risen to become a key arts and cultural visitor destination on the island of Tasmania.

Reflecting on the birth and subsequent growth of the domain, there is now a growing body of research in entrepreneurial marketing, with papers published in mainstream marketing, entrepreneurship and management journals in both regular and special issues. This Handbook provides reflection and synthesis at the interface of the two domains, alongside inputs from marketing and entrepreneurship. It also develops a consideration of a future business environ- 
ment shaped by creativity and innovation from marketing and entrepreneurship practitioners and researchers. There have also been several research-led books on entrepreneurial marketing (e.g. Bjerke and Hultman 2004; Sethna et al. 2013) and the Journal of Research in Marketing and Entrepreneurship continues to make a meaningful contribution to understanding entrepreneurial marketing theory and practice. Gilmore et al. (2013) note the diverse and often complex aspects of entrepreneurial marketing practice in national and international contexts. Representative areas of research include its theory and practice (Schindehutte et al. 2008; Jones and Rowley 2009; Miles et al. 2015), new ventures and growth (Miles and Darroch 2006), entrepreneurial and marketing orientations (Miles and Arnold 1991; Jones et al. 2013), the history of the entrepreneurial marketing construct (Collinson and Shaw 2001), regional activity (Hultman 1999), internationalisation (Fillis 2004; Kocak and Abimbola 2009; Mort et al. 2012), entrepreneurial marketing education (Carson and Gilmore 1997), its research methods (Carson and Coviello 1996; Gilmore and Carson 1999; Gilmore 2010; Fillis 2015) and its networks and relationships (Anderson and Jack 2002; Zontanos and Anderson 2004). Other relevant themes include opportunity recognition (Hulbert et al. 1997; Hansen and Hills 2004), entrepreneurial marketing mindfulness (Uslay and Erdogan 2014) and creativity (Fillis $2005,2010)$. In fact, the creative industries and cultural sector exemplify the practice of entrepreneurial marketing (Parkman et al. 2012) and where other sectors can learn from best practice.

There has also been a call for the interface between entrepreneurship and marketing to be recognised as a paradigm (Carson 2010). Hills and LaForge (1992:33) understand the intersection from a behavioural perspective:

Marketing behaviour and entrepreneurial behaviour are similar in nature - they are boundary spanning, involve extensive interplay with the environment, require the assumption of risk and uncertainty, and inevitably interface the complexities of human behaviour with commercial and other endeavours.

Connecting with the previously mentioned areas of research within the entrepreneurial marketing domain, Kraus et al. (2012) carry out an analysis in order to identify and strengthen any inherent relationships, identifying several streams: foundations of entrepreneurial marketing research, theoretical foundations of management, entrepreneurship and marketing, the research interface of marketing and entrepreneurship, SME and new venture marketing. A personalised management style is typical of any SME (Scholhammer and Kuriloff 1979), with the entrepreneurial marketer most effective at implementing a self-styled way of managing which succeeds in getting the most from his or her employees. If agreement is still to be reached about the paradigm issue, at least many researchers agree that embracing marketing and entrepreneurship indicates an evolving form of business philosophy and practice. Kraus et al. (2012) identify an interesting fact - that SME and new venture marketing research only really began to emerge from 2000 onwards. This is paralleled elsewhere; for example, in internationalisation-related research (e.g. Fillis 2001). Here SMEs have always had some international impact but their research has only recently been accelerating in tandem with increased globalisation and technology effects, and where barriers to market entry are now no longer viewed as impediments but as opportunities.

Where marketing and entrepreneurship are practised today has expanded well beyond their initial boundaries (Venkataraman 1997; Levy 2002). It could be argued that the creativity and innovation inherent in their practices, and to a lesser extent in their research methodologies, 
has impacted positively in expanding this impact. An additional factor which should be considered is the contribution of cross-disciplinary insight in further expansion of the domain. An example from one of the editors' own research interests is the value of insight from the art world in helping to improve understanding of marketing, entrepreneurship and entrepreneurial marketing practice from the perspective of the artist as an owner/manager (Fillis 2004). There is also merit in considering how the innovation and creativity in the art world can inform marketing and entrepreneurship theory and practice. Several of the authors contributing to chapters in the Handbook, for example, have previously researched how entrepreneurial marketing has contributed to the successful development of an arts and tourism venture (Lehman et al. 2014; Fillis et al. 2016) and how female artists practise as cultural entrepreneurial marketers (Rentschler 2007). Carson and Coviello (1996:56) also connect to this way of thinking by asserting that all practitioner-based research is artistic since it:

will use any method at its disposal, regardless of compatibility and correctness ...The concepts of rigour and validity seldom enter into the mind-frame. The practitioner will have a 'feel' for the value and usefulness of information and its source.

Other contributing domains which inform our understanding include sociology (Reynolds 1987), anthropology (Mendez 2009) and history (Svensson 2002). This list is not exhaustive as we continue to identify other potential contributors to improving understanding of entrepreneurship and marketing. In attempting to synthesise thinking around the domain, Miles et al. (2015) visualise its contributions around three axes; the vertical locus as strategy, the horizontal locus as culture and process, and the temporal locus as strategic response.

Chapter contributions to this book can help us to rethink the constructs within entrepreneurship and marketing. Marketing, for example, no longer relies on continued alignment to customer orientation, with stimulation of demand by businesses for innovative products, services and experiences. Also, consumers are increasingly at the forefront of innovative new product development via their co-production and co-creation activities (Prahalad and Ramaswamy 2004; Sanders and Stappers 2008; Penaloza and Mish 2011). Equally, entrepreneurship does not have to be solely to do with new venture start-ups, but rather as an overarching philosophy within the business. Entrepreneurial marketing, it can be argued, offers the best of both worlds in identifying and exploiting opportunities by leveraging a range of hard and soft competencies. We should be prepared as researchers to adopt alternative lenses to counter the long-standing causal approach to understanding in order to offer novel insights into entrepreneurship and marketing phenomena (Sarasvathy 2001). Owner/managers, for example, do not necessarily think in linear rational ways, so why should researchers always design their research in a way which does not match behaviour in the business world? Some of the chapters in this Handbook draw on conceptualisations, some are informed by quantitative data, others by qualitative insight or mixed methods.

Contributing to our understanding of entrepreneurship and marketing through a variety of viewpoints is refreshing and allows us to even re-imagine the future of these domains. Very often, insight lies within the situation specific, rather than through generalisations. Whatever perspective is held, by triangulating our views, we can hope to develop much more rigorous insight than if a single avenue of exploration alone was followed. 


\section{OVERVIEW OF THE CHAPTERS}

Stephen Brown and Anthony Patterson's chapter on epics, umbras and authorpreneurs provides a thought provoking follow-on from the introduction chapter where they set up the demise of both marketing and entrepreneurship in a tantalising way, before rescuing their futures by imagining new possibilities through innovative media forms and brand identities. Focusing on the epic rather than the mythological may well be the answer. Moving away from the marketing as an art or a science debate, Brown and Patterson leverage value from the arts and cultural sector in order to evaluate the future from an authorpreneurial perspective. Clues to the future of both marketing and entrepreneurship are extracted and debated by assessing actual and metaphorical practices contained in the work of major literati and authorpreneurs such as James Joyce, Samuel Beckett and Ernest Hemingway. Each had first-hand experience of the world of business and were not shy to get involved in the self-promotion marketplace. Samuel Beckett, though, was more of an anti-marketer but by proclaiming his anti-commercial stance he then created his own brand identity in any case. Brown and Patterson recommend examining what is happening in the shadows, or the umbra, in order to really understand what is occurring now and what can happen in the future from a bigger picture perspective.

Part II on SME strategy and networking begins with Audrey Gilmore's partially reflective account of networking from an SME perspective where she outlines the specific nature of the smaller firm in making considerable contributions to the economy in ways which are essentially different to the normative schemas set out in many textbooks and taught to business students. SMEs cannot generally afford to carry out business in formal ways, and so they often bypass these pathways to secure business via lower cost approaches such as networking and word of mouth communication. The owner/manager heavily influences networking activities through his or her range of personal and business contact networks. As the business becomes more experienced, networking is used in more strategic ways. Gilmore illustrates what occurs in practice by examining SME activities within a retail marketing channel and also, by way of comparison, from the perspective of SME networking from a dysfunctional regional heritage tourism supply chain.

Briga Hynes and Maria Kelly continue the evaluation of networking from an entrepreneurial marketing perspective by examining the interactional dynamics between the entrepreneur and network management. They begin by outlining how traditional marketing is ineffective for the situational SME context, instead positioning entrepreneurial marketing as the preferred response. Their review of the entrepreneurial marketing literature is supported by insight generated from qualitative in-depth interviews with entrepreneurs which uncover how their networks are sourced, what their roles are, the network adoption process and their management. This enables a more nuanced understanding of the internal dimensions of network associations, helping to address the limited understanding which exists on how the process of securing network benefits occurs. Hynes and Kelly make a series of recommendations for the future management of SME networks which involves more strategic evaluation over time.

The strategic focus is also developed by Rosalind Jones and Mari Suoranta in their chapter on entrepreneurial marketing from a strategic orientation and networks approach. In their evaluation of the SME marketing literature, in which they distinguish between new venture and SME practices, they outline the constraints which tend to impact, despite the development of digital marketing. They assess a variety of impacting orientations, from entrepreneurial marketing, strategy, market, customer, entrepreneurial and innovation perspectives. What 
heightens the value of Jones and Suoranta's chapter further is their conceptual model of SME entrepreneurial marketing orientation and their EMICO framework which identifies areas of commonality between the aforementioned orientations. Drawing on comparative empirical insight from small technology businesses, they identify six strategic network typologies and develop a strategic marketing networks model which promotes the creation of both physical and virtual networks in order to secure competitive advantage.

Darryl Cummins continues the strategic theme by firstly discussing the distinctive nature of the small firm when compared to its larger counterpart. One of the key contributions of this chapter is that it traces developments over a 15 -year time period with eight case firms, enabling meaningful insight to be generated as the business grows (or fails). Cummins evaluates the literature on strategy-making in small firms, noting that its practice is unplanned and emergent, informal and intuitive, often unclear, and is heavily influenced by the owner/manager. Caveats are also identified which impede effective progress, including poor communication of strategic objectives. Situation-specific understanding is also paramount, rather than attempting to develop a 'one-size-fits-all' approach.

We then assess contemporary developments in entrepreneurial marketing practice in Part III through a series of chapters which feature a variety of perspectives from finance to the social and even criminal contexts in order to show where and how entrepreneurial marketing plays out in the world of practice. Mawson and Ball's chapter, picking up on the popular yet under-researched phenomenon of crowdfunding in entrepreneurial finance, shares nascent research in the case of a French green energy company's foray into an alternative source of finance. They reveal the important point that attracting funds in this way makes an important contribution to garnering local stakeholder buy-in to potentially contentious windfarm projects. Indeed, the funding aspect is less important since projects are guaranteed to go ahead with traditional forms of finance so it may be argued that positive relationship building and public relations are the major motivator in adopting this form of finance.

Brian Jones draws upon the seminal work of Rittel and Webber (1973) in assessing the complex and intractable problems that society presents to public managers to consider the 'wicked problem' that social media presents to small and medium-sized business. While on the one hand social media provides a rich opportunity for SMEs and vast potential for their communications strategy, it also presents a number of difficult problems that combine to become 'wicked' in the sense that Rittel and Webber describe. The chapter gives a rich foundation from the literature and goes on to specify a number of salient issues for the entrepreneurial marketers trying to grapple with not only fast-moving technology but the needs of traditional forms of communication and the changing marketplace.

As part of a wider study on the exchange behaviours of mothers that draws on rich and narrative data collected thereon, Elaine Ritch and Anne M.J. Smith's chapter looks at the social entrepreneurial behaviours of mothers in respect of the exchange of clothes and other consumer goods. This is done with the backdrop of two competing grand narratives: Dominant Social Paradigm (DSP) and the New Political Economy (NPE). DSP contains political, social and economic dimensions and is characterised by the profit motive and consumption is motivated by aesthetics and esteem value. The NPE provides the conceptual space and possibility to accommodate new forms of exchange and in the context of entrepreneurial marketing, the potential to make micro-entrepreneurs out of consumers. The authors invoke in mothers the social entrepreneurial activity which makes best use of scarce resources as described earlier with reference to Gilmore et al. (2001). By using the bases of social, economic, political and 
sustainability value in conjunction with participant testimony the authors create a convincing image and argument for the role of micro-enterprise where the motivation is social and environmental rather than for monetary gain. The economic element, however, remains in the sense that participants in this social economy often benefit from financial savings in the activities they engage with in addition to the moral motivations they have in reducing waste and in encouraging responsible production and consumption.

Elaine Ramsey, Emer Gallagher, Andrew Kincaid and Sharon Loane also investigate crowdfunding but, in contrast to Mawson and Ball, they evaluate key crowdfunding approaches, develop an in-depth assessment of their regulations and the risks involved, before moving on to consider key crowdfunding campaign issues. They also identify the antecedents to crowdfunding for entrepreneurs, as well as the consequences involved.

Robert Smith and Liz Frondigoun's chapter on 'Rogue shopkeepers' links this particular type of criminal entrepreneur who form part of a larger white-collar crime milieu and who operate using the techniques of entrepreneurial marketing to increase success but not necessarily voluntary visibility. Using a combination of documentary evidence combined with life-story techniques the authors fashion an image of the shopkeeper as a mythical or historical trope then continue to describe and discuss the nature and behaviour of the rogue shopkeeper and how they are situated and operate often within disadvantaged communities. While the authors admit there is much more work to be done on this particular aspect within criminology and in entrepreneurial marketing research, they set the agenda here for what has hitherto received little attention in the academic literature in such an orientation.

Sharon Loane and Trevor Morrow assess how a human resource management (HRM) lens can aid our understanding of international entrepreneurship research. More specifically, they call for a strategic perspective on HRM within the smaller firm rapid internationalisation environment. Their conceptual chapter results in the construction of a range of research propositions, helped in part by drawing on the resource-based and knowledge-based views of the firm. As the firm grows there is an increasing need for relevant human resources to be accessed in order to support this expansion. The focus on human resources in this context introduces a degree of novelty but also necessity in this increasingly globalised world.

Innovative approaches to understanding entrepreneurial marketing in Part IV of the book are opened up by Jonathan H. Deacon and Elizabeth Lloyd-Parkes in their chapter on the use of a narrative methodology in small firm research. They set out the importance of grasping the potential of a narrative ontology in uncovering how a personal perspective on the world helps us to 'see' the real world of the owner/manager. This 'lived experience' perspective certainly contributes to the closing of the theory versus practice gap, helped by assessing the 'real' language of business. It is also important to acknowledge the social world surrounding decision making here in making wider connections to the world beyond the enterprise. In doing so, contextualisation of the circumstances should be addressed. This then challenges us to overcome any barriers, perceptual and otherwise, which we may have in building relevant theory for both researchers and practitioners.

Ian Fillis and Jonathan E. Schroeder embrace what may seem initially to be an unusual perspective in understanding leadership in the small firm. Taking their cue from organisational studies, they adopt an aesthetic lens as an entrepreneurial way of understanding SME leadership. The aesthetic lens has long been utilised in the arts and more recently in critical management studies but has, to date, been under-utilised in small business research. Their aesthetic leadership approach is investigated within the craft sector where pre-existing design aesthetics 
mingle with that of owner/manager leadership. The sensory nature found in our responses to art and craft can also be located in our decision-making abilities. The tangible and intangible intermingle here as the owner/manager secures improved understanding of how to lead within a micro-enterprise often suffering from severe resource constraints. A conceptualisation of aesthetic leadership is developed which can help researchers in other settings to embed an aesthetic lens in their research designs.

Serendipity is a common thread in the next two chapters (and is revisited later in the book by Preece and Telford). Saeed Mirvahedi and Sussie C. Morrish examine the inter-relationship between it, effectuation and entrepreneurial marketing within fast growth entrepreneurial firms, using a cross-cultural case study approach. Fast growth behaviour appears to be the result of entrepreneurial endeavour and luck. The serendipitous element is unplanned and unexpected but can have a positive impact by being in the right place at the right time in assisting opportunity development. It could be argued here that having a well-developed network of contacts can readily enable this to occur. Mirvahedi and Morrish's conceptual model helps to visualise how the various cogs of this mechanism fit together. Their qualitative approach to interviewing helps to unveil the real impact of the entrepreneur's network on achieving high growth rates. The cross-cultural approach taken showed that the value system of the entrepreneur is also important here. Kaye Nightingale and Zubin Sethna develop a model of entrepreneurial marketing which incorporates strategy, serendipity, storytelling and software perspectives. They adopt a 'role of the dice' perspective, demonstrating the part that serendipity plays in order to understand how entrepreneurs think, read, write and speak in order to make short-term decisions, while also considering the longer term. The idea here is to continue to utilise the model developed by the authors as the firm grows as a result of its flexible, creative and innovative endeavours.

Ahmet Bayraktar, Emine Erdogan, Can Uslay and Olivia F. Lee investigate the role of mindfulness in shaping entrepreneurial marketing for SMEs. They identify the limitations of a traditional marketing approach in the context of the SME, and develop a discussion of the similarities and differences between individual and organisational mindfulness in impacting on the firm. They develop the concept of mindful entrepreneurial marketing and apply this to the context of crowdfunding. A series of propositions are constructed around the concept which seek to differentiate the SME from the larger firm. The authors believe that mindfulness will be a key differentiator for the SME as it embraces both societal and marketing return. The authors also make connections to one of the editors' research interests - biographical research - in helping us to understand how the entrepreneur's story relates to mindful entrepreneurial marketing.

Peter J. Fraser and Iain S. Fraser consider the challenges experienced by the owner/manager and the individual businessperson. They evaluate the usefulness of marketing in this context, discussing the role that networking plays in developing sales leads. Use is made of qualitative insight from interviews with owner/managers in unveiling the central concerns of those working as solo entrepreneurs. Generalist advice is extremely limiting in this context, with learning by doing being the best alternative option. Interestingly, those interviewed by the authors never identified themselves as entrepreneurs, even though they may have been engaging in entrepreneurial activities throughout their years of practice. To complete the part on innovative practice Nicholas Telford and Veronika Gustafsson assume the mantle of academic entrepreneur in the meta discourse of promoting their institution, attracting prestige and developing international networks, experiences and learning opportunities for their students under 
an established European Union scheme. If such high aims were not enough it was hoped by university administrators to also be an opportunity to bring home the bacon in the form of extra revenue during tough times for trading. The authors adopt an autoethnographic approach in addition to a review of the project, its origins and initial feedback from students. The academic as entrepreneur is an established concept, as discussed in the chapter, but perhaps by using the dual lens of entrepreneurial marketing a new way of thinking may be used to negotiate future academic development from both a personal professional and larger institution point of view. The chapter certainly offers an insight into the practical misadventures of two aspirant entrepreneurial marketer academics.

The Handbook continues in Part V by focusing on entrepreneurial marketing in the arts and cultural industries in order to leverage understanding from an industry sector which is inherently creative and has much to offer in terms of informing understanding to both academics and practitioners in the SME and wider business arena. When assembling the chapters by theme, this turned out to be the most popular. Aside from the effect of the editors' interest and attendant networks, the prevalence of art and culture is probably explained not only by embedded creativity and innovation but also by how this can be successfully leveraged to achieve stability and growth despite many resource constraints. There are lessons here for other sectors more blessed with a wider variety of resources but which are often less innovative and certainly less creative. Finola Kerrigan, Ngan (Emily) Luong and Roger Shannon examine entrepreneurship and marketing in the film industry where they identify creativity as central to its existence. Entrepreneurial marketing has played a crucial role here in the birth and growth of the industry where community actions and individual motivations succeed in helping to develop innovative practices. At the heart of everything here is the spirit of cultural entrepreneurship. An extremely insightful historical uncovering of the technological development of the industry provides us with rich evidence of developing creative practice in front of, and behind, the camera lens. What is particularly interesting in this chapter is that the authors develop a balanced discussion of the merits concerning customer-centric versus market creating approaches to film making. In developing an entrepreneurial marketing mindset, this enables truly innovative products to be created, resulting in improved value for audiences. Victoria L. Rodner and Pieter Tjabbes assess how a spirit of entrepreneurship was embraced by the Brazilian cultural sector in order to protect the industry from external threats. Joint action between the cultural agents was key to the lobbying of effective cultural policies such as Lei Rouanet which has resulted in a national cultural fund, a tax-deductible patronage scheme and a future cultural and artistic investment fund. These mechanisms allow cultural organisations to bypass any reliance on philanthropic donations and direct government funding in an economy where other domains have greater priority. The authors identify how individuals, groups and organisations become institutionalising entrepreneurs in order to protect crucial cultural policy by leveraging their passion and creativity in proactive ways. The political possibilities in arts and culture can be seen here as arts professionals effectively fight for the rights and identity of the sector, often against government priorities elsewhere.

Noel Dennis and Michael Macaulay interrogate the world of jazz in order to embed the notion of improvisation in entrepreneurship and small business. The authors draw on Miles Davis for their inspiration in order to heighten understanding of their connection with organisational ambidexterity. One of the authors is also a jazz musician and this brings even more creative insight and practice into the discussion. They identify the importance of experimentation in Davis's work as something which small businesses should be pursuing if they want 
to differentiate themselves from the competition. Dennis and Macaulay also open up the possibilities for all those working in an organisation to be able to express their creative thinking. Kim Lehman, Ian Fillis and Morgan P. Miles assess how the creation of a new art venture, the Museum of Old and New Art (MONA) in Launceston, Tasmania, can be explained in part by the adoption of entrepreneurial marketing and effectuation lenses. As part of their chapter they uncover the role which David Walsh has played in shaping the museum, from his upbringing through to his interest in gambling and risk taking and a growing fascination in art. Underpinning this is a discussion of the entrepreneurial marketing literature, together with an evaluation of effectuation. This combined approach helps to uncover and explain how someone who started with nothing managed to shape the second most visited destination on the island of Tasmania. The creation of MONA also signals to those working in the arts and cultural industries what can be achieved by moving away from administrative constraints.

Ruth Rentschler assesses media discourse as a form of entrepreneurial marketing surrounding blockbuster exhibitions with their often exceptional audience sizes. The developed conceptual framework sets out the part played by critics in meaning making. Critical acclaim has the potential to raise the status of the exhibition beyond conventional forms of organisationally shaped communication. A critical comparison of the discourse surrounding the artists J.M.W. Turner and John Constable is carried out. The popularisation of blockbuster events helps to address the often skewed demographics surrounding art exhibitions, appealing to a broader audience base. Rentschler uses content analysis to develop a contribution to theory by assessing the inter-connections between events, helped by the identification of recurring patterns in media discourse.

Rachel Noorda assesses the role of international entrepreneurial marketing in the publishing industry in Scotland as part of the wider creative and cultural industries. Qualitative case study analysis is used to gain insight into how many small and medium-sized publishers can overcome barriers to growth and secure a foothold in the international marketplace by embracing an entrepreneurial marketing mindset. This is also representative of wider industry where 99 per cent of these firms are SMEs. The Scottish companies leverage the socio-cultural historical connections with overseas markets in order to survive and grow. The impact of the owner/ manager is central to success here through innovation, closeness to customers and successful opportunity seeking behaviour.

Theresa A. Kirchner, John B. Ford and Sandra Mottner investigate the contributions made by the adoption of entrepreneurial marketing in the strategic management and marketing of arts organisations. Successful practice in this context, they believe, does not just depend on having an entrepreneurial artistic spirit but that an entrepreneurial marketing influenced approach to management is also required. The authors adopt a holistic 'top-down' approach to assessing the roles played by the company directors in securing a healthy environment in artistic and financial terms. A proactive, risk taking, innovative stance is required in order to secure and maintain artistic success and organisational support.

Chloe Preece and Nicholas Telford investigate the roles played by 'lucky breaks' in the careers of visual artists as entrepreneurs. Power dynamics are assessed in order to help address, or at least understand, the inequalities at play here. Rather than focusing all of the artist's efforts on making art, it is often the case that other jobs are required to support this creative work. It is not, therefore, an equal playing field, and certainly not in terms of factors such as social class and gender. Serendipity is believed by artists to play a role and while this has been acknowledged as an important factor in the entrepreneurship literature from an arts and 
cultural perspective in this instance, it is actually used more casually as a branding technique whereas other factors such as class, gender and associated social capital provide the 'luck'. Drawing on qualitative data, the authors identify concerns by the artists about having a lack of control over their destiny. They may have strong artistic competencies but also believe they are often at the mercy of external forces which they cannot control.

Finally, the editors provide some concluding thoughts in Part VI.

\section{REFERENCES}

Alvesson, M. and Deetz, S. (2000), Doing Critical Management Research, London: Sage.

Anderson, A.R. and Jack, S.L. (2002), 'The articulation of social capital in entrepreneurial networks: a glue or a lubricant?', Entrepreneurship \& Regional Development, 14 (3), 193-210.

Arnould, E.J. and Thompson, C.J. (2005), 'Consumer culture theory (CCT): twenty years of research', Journal of Consumer Research, 31 (4), 868-82.

Bhave, M.P. (1994), 'A process model of entrepreneurial venture creation', Journal of Business Venturing, 9 (3), 223-42.

Bjerke, B. and Hultman, C. (2002), EM: The Growth of Small Firms in the New Economic Era, Cheltenham, UK and Northampton, MA, USA: Edward Elgar Publishing.

Bjerke, B. and Hultman, C. (2004), Entrepreneurial Marketing: The Growth of Small Firms in the New Economic Era, Cheltenham, UK and Northampton, MA, USA: Edward Elgar Publishing.

Blackburn, R. and Kovalainen, A. (2009), 'Researching small firms and entrepreneurship: past, present and future', International Journal of Management Reviews, 11 (2), 127-48.

Boyatzis, R.E. (1992), The Competent Manager, New York: John Wiley \& Sons.

Boyer, C.B. and Merzbach, U.C. (2011), A History of Mathematics, New York: John Wiley \& Sons.

Brownlie, D., Saren, M., Wensley, R. and Whittington, R. (eds) (1998), Rethinking Marketing: Towards Critical Marketing Accountings, London: Sage.

Carson, D. (2010), 'Interface research: a commentary on a commentary - ten years on', Journal of Research in Marketing and Entrepreneurship, 12 (1), 8-10.

Carson, D. and Coviello, N. (1996), 'Qualitative research issues at the marketing/entrepreneurship interface', Marketing Intelligence and Planning, 14 (6), 51-8.

Carson, D. and Gilmore, A. (1997), 'Teaching and researching interface marketing: a critique and some alternatives', Marketing Education Review, 7 (3), 11-21.

Carson, D., Cromie, S., McGowan, P. and Hill, J. (1995), Marketing and Entrepreneurship in SMEs: An Innovative Approach, Englewood Cliffs, NJ: Prentice Hall.

Colbert, F. and St-James, Y. (2014), 'Research in arts marketing: evolution and future directions', Psychology \& Marketing, 31 (8), 566-75.

Collinson, E. and Shaw, E. (2001), 'Entrepreneurial marketing - a historical perspective on development and practice', Management Decision, 39 (9), 761-6.

Conley, C.H. (1927), The First English Translators of the Classics, New Haven, CT: Yale University Press.

Copleston, F.C. (1946), A History of Philosophy: Bentham to Russell, Mahwah, NJ: Paulist Press.

Day, J. (1997), 'From the special editor. Special issue on the marketing/entrepreneurship interface: setting the context', Marketing Education Review, 7 (3), 1-9.

Deacon, J.H. and Harris, J. (2011), 'Contextual marketing: a conceptualisation of the meaning and operation of a language for marketing in context', Journal of Research in Marketing and Entrepreneurship, 13 (2), 146-60.

Deshpande, R. (1999), 'Foreseeing marketing', Journal of Marketing, 63 (3), 164-7.

Eggers, F., Kraus, S., Hughes, M., Laraway, S. and Snycerski, S. (2013), 'Implications of customer and entrepreneurial orientations for SME growth', Management Decision, 51 (3), 524-46.

Fayolle, A. and Riot, P. (eds) (2015), Rethinking Entrepreneurship: Debating Research Orientations, Abingdon, UK and New York: Routledge. 
Fillis, I. (2001), 'Small firm internationalisation: an investigative survey and future research directions', Management Decision, 39 (9), 767-83.

Fillis, I. (2002), 'An Andalusian dog or a rising star? Creativity and the marketing/entrepreneurship interface', Journal of Marketing Management, 18 (3-4), 379-95.

Fillis, I. (2004), 'The entrepreneurial artist as marketer: drawing from the smaller-firm literature', International Journal of Arts Management, 7 (1), 9-21.

Fillis, I.E. (2005), 'Guest editorial: Creativity and the nonprofit marketing organization', International Journal of Nonprofit and Voluntary Sector Marketing, 10 (4), 199-201.

Fillis, I. (2006), 'Art for art's sake or art for business sake: an exploration of artistic product orientation', The Marketing Review, 6 (1), 29-40.

Fillis, I. (2007), 'Celtic craft and the creative consciousness as contributions to marketing creativity', Journal of Strategic Marketing, 15 (1), 7-16.

Fillis, I. (2010), 'The art of the entrepreneurial marketer', Journal of Research in Marketing and Entrepreneurship, 12 (2), 87-107.

Fillis, I. (2015), 'Biographical research as a methodology for understanding entrepreneurial marketing', International Journal of Entrepreneurial Behavior \& Research, 21 (3), 429-47.

Fillis, I. and Rentschler, R. (2006), Creative Marketing: An Extended Metaphor for Marketing in a New Age, Basingstoke: Palgrave Macmillan.

Fillis, I., Lehman, K. and Miles, M.P. (2016), 'The Museum of Old and New Art leveraging entrepreneurial marketing to create a unique arts and vacation venture', Journal of Vacation Marketing, 23 (1), 85-96.

Gaddefors, J. and Anderson, A.R. (2009), 'Market creation: the epitome of entrepreneurial marketing practices', Journal of Research in Marketing and Entrepreneurship, 10 (1), 19-39.

Gartner, W.B. (1985), 'A conceptual framework for describing the phenomenon of new venture creation', Academy of Management Review, 10 (4), 696-706.

Gartner, W.B. (2010), 'A new path to the waterfall: a narrative on a use of entrepreneurial narrative', International Small Business Journal, 28 (1), 6-19.

Gilmore, A. (2010), 'Reflections on methodologies for research at the marketing/entrepreneurship interface', Journal of Research in Marketing and Entrepreneurship, 12 (1), 11-20.

Gilmore, A. and Carson, D. (1999), 'Entrepreneurial marketing by networking', New England Journal of Entrepreneurship, 2 (2), 31-8.

Gilmore, A., Carson, D. and Grant, K. (2001), 'SME marketing in practice', Marketing Intelligence and Planning, 19 (1), 6-11.

Gilmore, A., McAuley, A., Gallagher, D., Massiera, P. and Gamble, J. (2013), 'Researching SME/ entrepreneurial research: a study of Journal of Research in Marketing and Entrepreneurship (JRME) 2000-2011', Journal of Research in Marketing and Entrepreneurship, 15 (2), 87-100.

Goulding, C. (2005), 'Grounded theory, ethnography and phenomenology: a comparative analysis of three qualitative strategies for marketing research', European Journal of Marketing, 39 (3/4), 294-308.

Hagglund, B. (2007), History of Theology, St Louis: Concordia Publishing House.

Hansen, D.J. and Hills, G.E. (2004), 'Industry differences in opportunity recognition', Journal of Research in Marketing and Entrepreneurship, 6 (1), 18-32.

Hill, R.P. and Martin, K.D. (2014), 'Broadening the paradigm of marketing as exchange: a public policy and marketing perspective', Journal of Public Policy \& Marketing, 33 (1), 17-33.

Hills, G.E. and LaForge, R.W. (1992), 'Research at marketing interface to advance entrepreneurship theory', Entrepreneurship Theory and Practice, 16 (3), 33-60.

Hills, G.E., Hultman, C.M. and Miles, M.P. (2008), 'The evolution and development of entrepreneurial marketing', Journal of Small Business Management, 46 (1), 99-112.

Howorth, C., Tempest, S. and Coupland, C. (2005), 'Rethinking entrepreneurship methodology and definitions of the entrepreneur', Journal of Small Business and Enterprise Development, 12 (1), 24-40.

Hoy, F. (2008), 'Organizational learning at the marketing/entrepreneurship interface', Journal of Small Business Management, 46 (1), 152-8.

Hulbert, B., Berman, B.R. and Adams, S. (1997), 'Towards an understanding of "opportunity"', Marketing Education Review, 7 (3), 67-73. 
Hultman, C.M. (1999), 'Nordic perspectives on marketing and research in the marketing/entrepreneurship interface', Journal of Research in Marketing and Entrepreneurship, 1 (1), 54-71.

Hunt, S.D. (1994), 'On rethinking marketing: our discipline, our practice, our methods', European Journal of Marketing, 28 (3), 13-25.

Jones, R. and Rowley, J. (2009), 'Presentation of a generic "EMICO" framework for research exploration of entrepreneurial marketing in SMEs', Journal of Research in Marketing and Entrepreneurship, 11 (1), 5-21.

Jones, R., Suoranta, M. and Rowley, J. (2013), 'Entrepreneurial marketing: a comparative study' The Service Industries Journal, 33 (7-8), 705-19.

Joshi, A.W. (2016), 'When does customer orientation hinder (help) radical product innovation? The role of organizational rewards', Journal of Product Innovation Management, 33 (4), 435-54.

Kocak, A. and Abimbola, T. (2009), 'The effects of entrepreneurial marketing on born global performance', International Marketing Review, 26 (4/5), 439-52.

Kotler, P. and Levy, S.J. (1969), ‘A new form of marketing myopia: rejoinder to Professor Luck', The Journal of Marketing, 33 (3), 55-7.

Kraus, S., Filser, M., Eggers, F., Hills, G.E. and Hultman, C.M. (2012), 'The entrepreneurial marketing domain: a citation and co-citation analysis', Journal of Research in Marketing and Entrepreneurship, $14(1), 6-26$.

Lam, W. and Harker, M.J. (2015), 'Marketing and entrepreneurship: an integrated view from the entrepreneur's perspective', International Small Business Journal, 33 (3), 321-48.

Landstrom, H. and Lohrke, F.T. (2010), Historical Foundations of Entrepreneurship Research, Cheltenham, UK and Northampton, MA, USA: Edward Elgar Publishing.

Lehman, K., Fillis, I. and Miles, M. (2014), 'The art of entrepreneurial market creation', Journal of Research in Marketing and Entrepreneurship, 16 (2), 163-82.

Levy, S.J. (2002), 'Revisiting the marketing domain', European Journal of Marketing, 36 (3), 299-304.

Libai, B., Bolton, R., Bügel, M.S. et al. (2010), 'Customer-to-customer interactions: broadening the scope of word of mouth research', Journal of Service Research, 13 (3), 267-82.

Mendez, C. (2009), 'Anthropology and ethnography: contributions to integrated marketing communications', Marketing Intelligence and Planning, 29 (5), 633-48.

Miles, M.P. and Arnold, D.R. (1991), 'The relationship between marketing orientation and entrepreneurial orientation', Entrepreneurship Theory and Practice, 15 (4), 49-66.

Miles, M.P. and Darroch, J. (2006), 'Large firms, entrepreneurial marketing processes, and the cycle of competitive advantage', European Journal of Marketing, 40 (5-6), 485-501.

Miles, M., Gilmore, A., Harrigan, P., Lewis, G. and Sethna, Z. (2015), 'Exploring entrepreneurial marketing', Journal of Strategic Marketing, 23 (2), 94-111.

Mitchelmore, S. and Rowley, J. (2010), 'Entrepreneurial competencies: a literature review and development agenda', International Journal of Entrepreneurial Behaviour and Research, 16 (2), 92-111.

Morris, M.H., Schindehutte, M. and LaForge, R.W. (2002), 'Entrepreneurial marketing: a construct for integrating emerging entrepreneurship and marketing perspectives', Journal of Marketing Theory and Practice, 10 (4), 1-19.

Morrish, S.C. (2011), 'Entrepreneurial marketing: a strategy for the twenty-first century?', Journal of Research in Marketing and Entrepreneurship, 13 (2), 110-19.

Morrish, S., Coviello, N., McAuley, A. and Miles, M. (2015), 'Entrepreneurial marketing: is entrepreneurship the way forward for marketing?'. In M. Dato-on (ed.), The Sustainable Global Marketplace. Developments in Marketing Science: Proceedings of the Academy of Marketing Science, Cham: Springer, p. 446.

Mort, G.S., Weerawardena, J. and Liesch, P. (2012), 'Advancing entrepreneurial marketing', European Journal of Marketing, 46 (3/4), 542-61.

Neck, H.M., Meyer, G.D., Cohen, B. and Corbett, A.C. (2004), 'An entrepreneurial system view of new venture creation', Journal of Small Business Management, 42 (2), 190-208.

Neugebauer, O. (2012), A History of Ancient Mathematical Astronomy (Vol. 1), Berlin: Springer Science $\&$ Business Media.

Parkman, I.D., Holloway, S.S. and Sebastiao, H. (2012), 'Creative industries: aligning entrepreneurial orientation and innovation capacity', Journal of Research in Marketing and Entrepreneurship, 14 (1), 95-114. 
Penaloza, L. and Mish, J. (2011), 'The nature and processes of market co-creation in triple bottom line firms: leveraging insights from consumer culture theory and service dominant logic', Marketing Theory, 11 (9), 9-34.

Peredo, A.M. and McLean, M. (2006), 'Social entrepreneurship: a critical review of the concept', Journal of World Business, 41 (1), 56-65.

Prahalad, C.K. and Ramaswamy, V. (2004), 'Co-creation experiences: the next practice in value creation', Journal of Interactive Marketing, 18 (3), 5-14.

Rentschler, R. (2007), 'Painting equality: female artists as cultural entrepreneurial marketers', Equal Opportunities International, 26 (7), 665-77.

Reynolds, P.D. (1987), 'New firms: societal contribution versus survival potential', Journal of Business Venturing, 2 (3), 231-46.

Rittel, H. and Weber, M. (1973), 'Dilemmas in a general theory of planning', Policy Sciences, 4, 155-69.

Sanders, E.B.N. and Stappers, P.J. (2008), 'Co-creation and the new landscapes of design', Co-design, $4(1), 5-18$.

Sarasvathy, S. (2001), 'Causation and effectuation: toward a theoretical shift from economic inevitability to entrepreneurial contingency', Academy of Management Review, 26 (2), 243-63.

Sarasvathy, S.D. (2009), Effectuation: Elements of Entrepreneurial Expertise, Cheltenham, UK and Northampton, MA, USA: Edward Elgar Publishing.

Saren, M., Maclaran, P., Goulding, C., Elliott, R., Shankar, A. and Catterall, M. (2007), Critical Marketing. Defining the Field, Oxford: Butterworth-Heinemann.

Schindehutte, M., Morris, M.H. and Kocak, A. (2008), 'Understanding market-driving behavior: the role of entrepreneurship', Journal of Small Business Management, 46 (1), 4-26.

Schindehutte, M., Morris, M.H. and Pitt, L.F. (2009), Rethinking Marketing: The Entrepreneurial Imperative, Upper Saddle River, NJ: Pearson Prentice Hall.

Scholhammer, H. and Kuriloff, A. (1979), Entrepreneurship and Small Business Management, New York: John Wiley \& Sons.

Sethna, Z., Harrigan, P. and Jones, R. (eds) (2013), Entrepreneurial Marketing: Global Perspectives, Bingley, UK: Emerald Group Publishing.

Shaw, E. (1999), 'Networks and their relevance to the entrepreneurial/marketing interface: a review of the evidence', Journal of Research in Marketing and Entrepreneurship, 1 (1), 24-40.

Sheth, J.N., Sisodia, R.S. and Sharma, A. (2000), 'The antecedents and consequences of customer-centric marketing', Journal of the Academy of Marketing Science, 28 (1), 55-66.

Solé, M. (2013), 'Entrepreneurial marketing: conceptual exploration and link to performance', Journal of Research in Marketing and Entrepreneurship, 15 (1), 23-38.

Svensson, G. (2002), 'Efficient consumer response - its origins and evolution in the history of marketing', Management Decision, 40 (5), 508-19.

Tadajewski, M. and Brownlie, D. (2008), Critical Marketing. Issues in Contemporary Marketing, Chichester, UK: Wiley.

Tedmanson, D., Verduyn, K., Essers, C. and Gartner, W.B. (2012), 'Critical perspectives in entrepreneurship research', Organization, 19 (5), 531-41.

Uslay, C. and Erdogan, E. (2014), 'The mediating role of mindful entrepreneurial marketing (MEM) between production and consumption', Journal of Research in Marketing and Entrepreneurship, 16 (1), 47-62.

Venkataraman, S. (1997), 'The distinctive domain of entrepreneurship research', Advances in Entrepreneurship, Firm Emergence and Growth, 3 (1), 119-38.

Whalen, P., Uslay, C., Pascal, V.J. et al. (2016), 'Anatomy of competitive advantage: towards a contingency theory of entrepreneurial marketing', Journal of Strategic Marketing, 24 (1), 5-19.

Zontanos, G. and Anderson, A.R. (2004), 'Relationships, marketing and small business: an exploration of links in theory and practice', Qualitative Market Research: An International Journal, 7 (3), 228-36. 